\title{
EFL Teachers' Perspective on Online Learning System under COVID-19
}

\author{
Yosefina Helenora Jem ${ }^{1}$, Tobias Gunas ${ }^{2}$, and Raymundus Beda ${ }^{3}$ \\ \{jemyosefina@gmail.com¹, tobgun74@gmail.com², raimundusbeda1968@gmail.com³ \\ UNIKA St. Paulus, Ruteng ${ }^{123}$
}

\begin{abstract}
Pandemic COVID-19 has changed the conventional learning system into an online learning system. Teachers and students have been teaching and learning from home since the pandemic has attacked humans globally. This becomes an interesting phenomenon to be investigated. This research aims at investigating the EFL teacher perspective in Ruteng on online learning systems under COVID-19. Three points, namely types of application used, the advantages and disadvantages of carrying out online learning system are the points of investigation. Twenty EFL teachers have been involved in this research. They were asked to write an English essay on how they run the teaching and learning process through the online learning system within the pandemic. The collected essays were read one by one to find the types of application used in online learning by the EFL teachers and identify the advantages and disadvantages of online learning from the EFL teachers 'perspective. The result reports that the EFL teachers use several types of applications in TLP; namely, WhatsApp, google classroom, google meet, messenger, and zoom. The results also underline that the accessibility of online learning is beneficial for EFL teachers. It improves EFL teachers' cognitive skills in technology and causes costeffectiveness on time and money. However, poor communication, lack of motivation, lack of quality, and some technical problems are the obstacles of an online learning system. Regarding to the result above, it is concluded that EFL teachers in Ruteng used more than one application in teaching-learning English. They also consider that online learning has a positive and negative impact on teachers and students.
\end{abstract}

Keywords: COVID-19 pandemic era; EFL teachers 'perspective; online learning

\section{Introduction}

The massive spread of coronavirus (COVID-19) around the world has become a global problem. This virus which started in China at the end of 2019, widespread increasingly. It was reported by WHO that the cases have been growing globally [11 \& 21]. Furthermore, WHO [22] mentions that in Indonesia, more than 1.500 cases were confirmed positively infected by the COVID-19 virus.

The spread of this virus has influenced all aspects of human life, including education. A new model of teaching-learning process (online learning) is introduced. The conventional (faceto-face) teaching-learning process has been changed into the online learning system. Since 17 March 2020, schools in the affected area are instructed to run the online learning system by the Minister of Education and Culture of Republik Indonesia [13]. Later on, due to the improvement of the cases and in order to maintain the health of teachers, students, and educational staff, all educational units are instructed to carry out online learning from 24 March 2020 by the 
department [12]. Along with this instruction, the governor of East Nusa Tenggara Province has ordered all educational units in his province to apply the online learning system [6]. Those instructions allow both teacher and student to teach and study from home, which totally differs from the face-to-face learning system [3].

Simply, online learning can be described as the use of technological devices such as computers and the internet in the teaching and learning process. Online learning is defined as the use of computers and the internet to provide a huge solution in order to facilitate learning and increase performance [8]. It enables teachers to share material forms such as word documents, PowerPoint, pdf, video, etc. It also facilitates teacher and student to run webinars, has communication through a comment or discussion forum. It gives teacher and student an atmosphere of the classroom teaching-learning process. Furthermore, online learning is defined as distance learning where teachers and students are in different places and the learning material is delivered using telecommunication tools [20].

Studies in online learning systems have been done by researchers. Researchers have reported that the use of Google classroom in an online learning system is valuable for both teacher and student [20]. It is also assumed that online learning is beneficial for the selfdevelopment of teachers [1]. Besides, other researchers claim that online learning provides advantages for multi fields [14]. In the context of the use of online learning systems under COVID-19 pandemic era, Raheem and Khan [18] emphasize that the use of various applications for learning is very helpful for students during the pandemic. Supporting Raheem and Khan, Okmawati [16] underlines that the use of Google Classroom in online learning during COVID19 pandemic is beneficial for English teachers and their students. Researches in online learning during COVID-19 pandemic done by Raheem and Khan [18] and Okmawati [16] have been completed. Yet, it is silently mentioned that study in online learning under pandemic in EFL context which is specially focused on EFL teachers' perspective is still infrequent.

EFL teachers have been considered as one of the important elements in English language teaching. Their role in English language class has been mentioned as a factor to determine the success of English learning. They have a responsibility to create an interactive teaching-learning process [9]. An interactive teaching-learning process provides a good atmosphere for teachers to discuss the material, motivate their students, gives input and chance for students in learning English and promotes intimate social relationship between teachers and students. However, the input and chance to use English in the classroom is hard to be carried out for nowadays. It is due to the COVID-19 pandemic.

The COVID-19 pandemic results online learning where the teaching and learning process is carried out from home. EFL teachers are not the exception. They must run their classroom activity from home under this pandemic. That's why; it is crucial for knowing their perspective on online learning. Simply, perspective is defined as perception, which refers to the ability of five senses to realize an object of a phenomenon [9kusmaryati]. There are three aspects that influence someone's perception, namely the perceiver, the target of perception and the situation [Robin].

A study on EFL teachers' perspective on online learning under COVID-19 pandemic has been mentioned as relatively low in the previous paragraph. However, a study from Atmojo and Nugroho can be found as a study that speaks about EFL teachers' perspective on online learning under this pandemic [3]. Through their study, Atmojo and Nugroho underline that in running online learning, EFL teachers in Indonesia use various applications to facilitate their classroom interaction. Further, it is mentioned by them that some challenges have occurred both for teachers and students. Yet, they ignore that there is a possibility that running online learning in this pandemic has a positive impact on EFL teachers. 
Regarding the explanation and previous study mainly conducted by Atmojo and Nugroho, this article wants to investigate how English teachers in Ruteng run the online learning system, the positive and negative impacts of running an online learning system under COVID-19 pandemic.

\section{Methodology}

This research has been carried out as descriptive qualitative research. It is naturalistic, and the data were descriptive [5]. This research has been conducted in Ruteng City, East Nusa Tenggara Province. Like in other cities in Indonesia, in Ruteng, English is learned as a foreign language at school. Teachers and students do not use English in their daily communication, both written and oral. Twenty teachers have been taken as the participants in this research which consist of ten female and ten male teachers. They were chosen based on the following criteria: (1) They are graduated from English Department from university, (2) They are English teachers of junior and senior high schools in Ruteng, and (3) they have been teaching for more than three years.

To gain the data, those teachers were asked to write an essay on their teaching-learning process within the COVID-19 pandemic era. Their essays are their reflection on how they carry out online learning. In the essay, they must include the information on (1) how they run the teaching and learning process within the pandemic (kinds/types of learning applications (such as WhatsApp, GCR, messenger, etc.), (2) the positive impacts of running online learning system for the teachers and (3) the negative effects running online learning system for them. After collecting, the researchers give code on the essays such as T1, T2, T3...T20.

With respect to the first aim of the study, the researchers use all the information about the type of application used in online learning given by those 20 EFL teachers. However, seven essays are chosen to be analyzed for the sake of the second and third aims. They are chosen due to its completeness of the information. Those essays then functioned as the source of data. Furthermore, those collected data are analyzed through some procedures as suggested by Mahsun [10], namely data reduction, data display, and verification/conclusion drawing.

\section{Findings and Discussion}

The findings in this research are discussed in detail based on three main points of investigation as follows:

\subsection{Types of application/s used by the EFL teachers}

The EFL teachers in Ruteng run an online learning system by using various types of applications, namely WhatsApp, google classroom, google meet, messenger, and zoom. It is in line with the study result where it is mentioned EFL teachers in Indonesia used several applications and platforms in running their online class [3]. The number of applications used by each EFL teachers can be seen in the following table: 
Table 1. Numbers of teachers and applications used in EFL classroom

\begin{tabular}{cc}
\hline Number of applications & Number of teachers \\
\hline 1 & 2 \\
2 & 13 \\
3 & 5 \\
Total & 20 \\
\hline
\end{tabular}

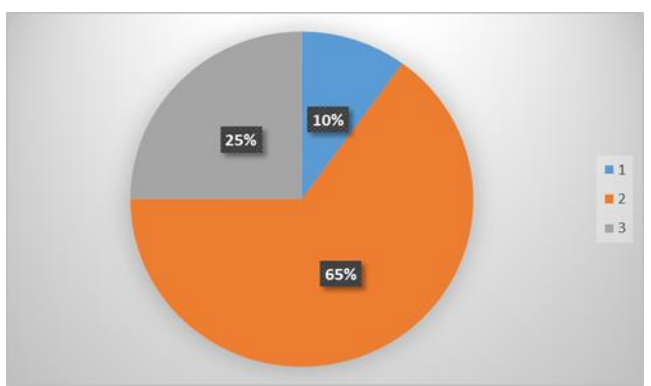

Fig 1. The percentage of EFL teachers based on the number of applications used in TLP

Based on the data in table 1 and figure 1, it can be said that most EFL teachers (13 teachers) used two applications to carry out the online learning system $(65 \%)$. It is followed by five teachers who use three applications (25\%). However, the EFL teachers who used one type of application are only two teachers out of twenty (10\%). Moreover, the data indicated that the maximum number of applications used by the EFL teachers are tree applications.

Using more than one application in the teaching and learning process (TLP) in online learning within the pandemic is crucial for teachers. They use it for different purposes. For example, teachers use two applications, such as WhatsApp and zoom, to deliver the material and have face-to-face classroom meetings with students. There are also teachers who use Google Classroom and Google Meet. While others use three applications, namely WhatsApp, Google Classroom, and Google Meet.

T8. I use WhatsApp and zoom to run my English class during this pandemic. I use WhatsApp for sharing material like in PowerPoint, word documents, and video. However, the zoom is very helpful when I want to explain the material directly to my students, like in face-to-face classroom meetings.

T12. I use google classroom, WhatsApp, and google meet in learning with my students during COVI-19. WhatsApp is for delivery material and video, google classroom for giving tasks and examinations. At the same time, google meet to discuss with my students.

T8 and T12 confirmed that they have different applications to carry out the online learning system. The use of different applications depends on the purpose of the teachers. For instance, if the teachers want to share material and video, they can use WhatsApp. While, when they want to give task and examination for students, they can use google classroom. However, zoom and google meet are used when the teachers want to explain and discuss the material directly to students like in a conventional system (face to face classroom meeting). It is in line with 
Sukmawati and Nensia saying that: in online learning, the learning material is delivered by using telecommunication tools [20].

\subsection{Advantages of running an online learning system}

The COVID-19 has affected the human's way of life, including education. Since the pandemic has attacked human globally, the learning system also changes its form. Schools start online learning systems to facilitate the teaching-learning process. Online learning is found as an effective way to keep the teaching-learning process running well. EFL teachers in Ruteng also carry out this learning system in learning English. They claim that the online learning system supports them in doing learning activities. They mention that online learning leads them to some positive points, as follows:

\section{Easy to access}

Online learning system stresses on the use of computers and the internet in the teachinglearning process. This learning system enables EFL teachers to run the teaching-learning process from anywhere without attending the class directly. They do not have to worry about their geographical location since what they need are only a computer/laptop and internet connection. It means that teachers and students can carry out teaching and learn from anywhere [19].

T14. I love teaching English through online learning. It is not difficult for me because I just need my laptop and internet connection. I live in Ruteng where the internet connection is stable, so I can have good access to the internet to teach my students.

T16.in online learning, I can teach my students from home. I do not must go to school everyday like before. Online learning is easy to access and help me much in teaching English for my students specially when I want to send my material, task and give examination for my students.

T14 and T16 mention that the accessibility of online learning is beneficial for them. They can access the internet from anywhere as what specifically mentioned by T16 that, he accesses the internet from home to teach English. However, T14 explains that she only needs a stabil internet connection to run the class.

\subsection{Improves EFL teachers 'cognitive skill in technology}

The online learning system directs the EFL teachers to deal with technological devices during working time. Sending material, delivering tasks, giving examinations, and doing discussions with students are done through the computer and the internet. To be successful in completing those activities, the EFL teachers must be able to operate the computer and understand the function, characteristics, and how each type of application works.

T5. The online learning system help me to understand the function and way of working of learning applications. For example, I know that I can share material, task, and examination through WhatsApp, but it will be difficult for me to give score and comment for my students' task and examination. I then discussed it with my friends, and one of my friends suggests me to use google classroom. After that, I searched in the internet about google classroom, its benefit and how to operate it. I then decided to use google classroom to give task and examination for my students because it helps me to correct, give comment and score on my students' papers. The problem also happen when I want to explain the material for my students directly. When I use video call in WhatsApp, I am not satisfied. I then tried to find an appropriate application 
for it, and based on the information I got, zoom application is suitable for me to explain my topic to my students directly like in the classroom because I can see my students face in zoom. They also can give question by chatting or raised hand. Here, I can say that online learning helps me to develop my knowledge to find a suitable application in teaching English for my students and how to work with the application.

Regarding the information given by T5, the EFL teacher mentioned that online learning systems enrich EFL teachers' knowledge on the types, characteristics, and functions of each type of learning application. Teachers have space to choose an appropriate application to be used in the teaching-learning process. They can facilitate all their activities such as explaining the material, distributing the material, task, or examination, having a discussion with students, and correcting and scoring students' work.

\subsection{Causes cost-effectiveness on time and money}

Another positive effect of running an online learning system is causing effectiveness on time and money. Since the online learning system has provided an opportunity for teachers and students to teach and learn from home, it automatically saves teachers' and students' time and money. Teachers or students do not need to waste time traveling from home to school or vice versa [2 \& 4]. They do need to be worried about being late or getting bemo or spending too much time on the way. Moreover, an online learning system helps teachers to save money for transportation. As online learning can be carried out from home, teachers will not need to pay for ojek or bemo. They also do not have to pay for snacks or lunch when they have full-time class in a day.

T1. Usually, I wake up early in the morning (4 o'clock) to prepare myself before go to school. I also must find bemo or ojek for my transportation so I can be on time arrive at school. Occasionally, when I'm not able to attend the classroom, I will get difficulties to reschedule my class meeting because my students must follow another class based on the schedule and the total of classroom in our school is not enough. But now, in online learning I can reschedule my class and do it in the afternoon or at night. Sometimes, when I have full schedule at school, I must have a cup of tea with cakes or even have lunch, I need to have extra money to pay for my lunch. But now, I do not need to wake up too early in the morning, pay for ojek or bemo or for my lunch because I do everything from my home.

Considering the description of T1, online learning does not push the teacher to spend much time traveling from home to school. It also saves the teacher's money from paying a number of fees such as transportation.

\subsection{Disadvantages of running an online learning system}

In spite of the positive effects of running online learning under the COVID-19 pandemic, EFL teachers in Ruteng claimed that online learning also has some negative effects as follows:

\section{Poor Communication}

In online learning, teachers and students are indifferent places. They are not in the same classroom as in a conventional learning system. Teachers are difficult to have a close interaction with the students - online learning limits communication between teachers-students and students-students. 
T20. It is difficult to have good communication with students. Most of the students are not active during our zoom meeting. For example: when I explain the material, my students are silent, and at the end of the explanation, I ask my students: do you understand, they just say 'yes. It is very different when we have classroom meeting. My students are so active, even I am in the middle of my explanation, they raise questions if they do not understand the topic.

T14. I have problem in doing communication with my students. I cannot check one by one to make sure that they really understand the topic of discussion. It is also difficult for me to ask my students to practice a dialogue or read aloud a text during the class. Before run the online learning, I can give task to be completed in a group for example make a dialogue and perform it in front of the class. But now, I cannot ask my students to complete exercise in a group.

Concerning the information given by T20 and T14, they emphasize that online learning system is lack interaction between teacher and students. It does not provide a good atmosphere for students to raise the question when they find difficulties in understanding the topic. In this situation, the teacher may feel alone and isolated and miss direct social interaction with students in the classroom. Furthermore, it is difficult for the teacher to let their students practice several topics verbally, by students' and the opportunity to practice the lesson is limited [19]. Furthermore, they mention that it is problematic to deliver the task to be completed in the group due to the difficulties of gathering the students. The lack of interaction also occurs between students. As it is difficult for teachers to give the task to do in a group, students do not have a chance to get in touch with their friends in completing the task. It underlines Arkoful's idea who mentions that the e-learning method causes a lack of communication in the teaching-learning process.

\subsection{Lack of Motivation}

To be successful in online learning, teachers and students must have strong motivation. They are asked to manage their time and keep the online learning well.

T5. I always give exercise and examination to my students based on the schedule given by school. I send them through google classroom. I was disappointed when correcting my students' work. There are students who just copy and paste from the internet when I give the task. It also happen when I am correcting their examination. I found that some of my students have the same answers. I found that they have right and wrong answers in the same number of test.

T8. in online learning, most of my students are late in joining the meeting. Just 5 or 7 students who are on time. It is happen so many times. They also are late in collecting their task. Besides, some of them are not prepare themselves before the class. They do not have a book, dictionary or pen with them while learning. They are not polite. For example, some of them follow the class while lying down on the bed, talk to people around them, or do other things while learning.

T5 describes that it is hard to find students' original work. Students depend much on the internet or friends to complete the task or examination given by the teacher. They are not motivated to complete the given task or exam by themselves during the online learning takes place. Moreover, on the basis of T8's information, it is found that students do not have motivation in learning. They do not force themselves to be on time in attending the class or completing the tasks. They do not make any preparation before joining the class. Furthermore, students' attitude during the class becomes another problem that occurs in the online learning 
system. They do not concern about the class because they are doing another thing. It is easy for students to be distracted by other things [7]. Their attitude while listening to the teacher is unpolite. Students' bad attitudes while joining the meeting are very hard to be controlled by the teacher. Facing students' unpolite acts may bring bad effects for teachers that can influence the teaching-learning process. This bad attitude is the result of the lack of motivation, which can lead students to fail in completing online learning.

\subsection{Lack of Quality}

As an online learning system sets teachers and students to teach and learn from home, every teaching-learning process, including giving tasks and examination, is done through the internet. This system results in lack of quality in the teaching-learning process [7].

T5. I always give exercise and examination to my students based on the schedule given by school. I send them through google classroom. I was disappointed when correcting my students' work. There are students who just copy and paste from the internet when I give the task. It also happen when I am correcting their examination. I found that some of my students have the same answers. I found that they have right and wrong answers in the same number of test.

T12. In online learning, it is difficult for me to examine my students' ability or improvement in learning. I found that their task or exam result are high. It is different when I compare with the result of their task and exam in face to face classroom. I don't mean to underestimate my students, but I doubt that their task or exam are their original work. It is because when I have a chance to communicate with them in English in our meeting, they do not give respons and just keep silent. I am confused how can they have high score, where or how they get the answers or who do their task and exam.

T5 stresses that in online learning, he faces difficulties to find students' original work in completing the task and examination. Online learning opens a huge opportunity for students to cheat or do plagiarism. It is in line with [2], who mentions that online learning leads students to bad activities like cheating, piracy, and plagiarism as well as copy and paste.

Furthermore, T12 claims that online learning does not provide accurate data to examine students ' development in learning. The test result of the online examination is not able to help teachers to measure students' improvement in learning English. Students' test result may become a fake result as they find that their students' score in the test are not in line with their performance in real meeting. Teachers disbelieve that their students complete the exam by themselves. On the basis of the explanation above, it can be mentioned that students performance and/or quality in online learning is low. They lost their best performance in learning English.

\subsection{Some technical problems}

Computer/laptop/android and internet connection enable teachers and students to run the online learning system. Without having one of them, it is impossible for both teachers and students to complete this learning system. Those three things facilitate the success of an online learning system. Losing one of those three things will ruin the completeness of the online learning system.

T1. I use a laptop and need internet access in teaching from home. I deliver my material, run my zoom meeting, give task and exam by internet. However, sometimes it cannot be done 
because the internet connection is very bad. I then cancel my zoom meeting and rearrange the meeting. I also resent my material or task when I get problem with the internet.

T16. ... have students who do not have android. It is difficult for them to follow the online class. They miss the zoom meeting and are not able to do the task or examination.

T1 and T16 underline that having a computer/android and internet connections is a must in running online learning. It emphasizes the idea of [7] idea: the objective of online learning cannot be achieved with the absence of hardware, software, and a stable internet connection.

\section{Conclusion}

EFL teachers in Ruteng have conducted online learning systems under the COVID-19 pandemic era. Numbers of applications, namely WhatsApp, google classroom, zoom, google meet, and messenger have been used by the teachers to facilitate the success of online learning. Running online learning within the pandemic provides some positive things for teachers, such as ease to access, increase teachers' knowledge and skill in technology and save teachers' time and money.

Yet, for some points, online learning has weaknesses. It blocks the communication between teacher and students as well as student and student. It decreases students' motivation and quality in learning. In addition, technical problems like unstable internet connection and the absence of a computer or android are another obstacle to online learning. In order to reduce the negative effect of online learning, some suggestions are delivered as follows: teachers are asked to be more creative in running the online class within the pandemic. They are suggested to be able to motivate and keep in touch with students. Their fast response is a must to build effective communication with students. Furthermore, they are also hoped to facilitate students who do not have a computer or android to have access in class.

Aside from teachers, students must be able to focus and manage their time well. Without having good focus and time management, they will not be able to complete their online class. Students are also advised to motivate themselves in learning. They need to be on time in joining the class or collecting the task. It is a must for them to do the task or exam by themselves to prevent them from cheating and doing plagiarism. Besides, they must stay at a place with a stable internet connection.

To add, parents are also asked to support their children in completing their online class by providing computer/android and money for internet quota. Finally, successful online learning does not only depend on teachers. It also asks government's responsibility. That is why they are suggested to provide well internet connection for all teachers and students in Indonesia, especially in Ruteng. They also need to work together, hand in hand with schools to help students having no android or computer to have access to them.

\section{References}

[1] Anderson, J: IT, E-Learning and Teacher Development. Vol. 5(5), 1-14. International Education Journal (2005).

[2] Colorful, Valentina \& Nelly Abaidoo: The Role Of E-Learning, The Advantages, And Disadvantages of Its Adoption in Higher Education. Vol. 2 (12), 397-410. International Journal of Education and Research. (2014) 
[3] Atmojo, Arief Eko Priyo., \& Arif Nugroho: EFL Classes Must Go Online! Teaching Activities and Challenges during COVID-19 Pandemic in Indonesia. Vol. 13, pp. 49-76. Register journal (2020)

[4] Bijeesh, N. A: Advantages and disadvantages of distance learning. Retrieved from http://www.indiaeducation.net/online-education/articles/advantages-and-disadvantages-ofdistancelearning.html. (2017)

[5] Bogdan, Robert C \& Sari Knopp Biklen: Qualitative Research for Education: An Introduction to Theories and methods. Pearson, New York (2006)

[6] Cici: Instruksi Gubernur NTT: Tahun Ajaran 2020/2021 Mulai 20 Juli 2020. Retrieved from https://www.sergap.id/instruksi-gubernur-ntt-tahun-ajaran-2020-2021-mulai-20-juli-2020/ (2020)

[7] Dhull, Indira \& Sakshi: Online Learning. Vol. 3 (8), 32-34. International Education and Research Journal (2017)

[8] Gherardini, B. E-learning methodologies: A guide for designing and developing e-learning courses. Food and Agriculture. Organization of the United Nations (2011)

[9] Kusmaryati, Sri Endang: Teachers' Perspective of Teaching English to Young Learners (A Descriptive Study at Primary School in Kudus). Vol. 7 (2), pp. 93-103. ELT Worldwild. (2020)

[10] Mahsun, M.S: MetodePenelitan Bahasa: Tahapan Strategi, Metode, dan Tekniknya. Raja Grafindo Persada, Jakarta (2005)

[11] McAleer, M: Prevention Is Better Than the Cure: Risk Management of COVID-19. Journal of Risk and Financial Management, 13(3). https://doi.org/10.3390/jrfm13030046 (2020).

[12] Mendikbud. Surat Edaran Mendikbud: Pelaksanaan Kebijakan Pendidikan dalam Masa Darurat $\begin{array}{llll}\text { Penyebaran Corona Virus Disease } & \text { (COVID-19). } & \text { Retrieved }\end{array}$ fromhttp://kemdikbud.go.id/main/files/download/51e9b72ef92c6d8 (2020a)

[13] Mendikbud. Surat Edaran Mendikbud: Pembelajaran secara Daring dan Bekerja dari Rumah dalam Rangka Pencegahan Penyebaran Corona Virus Disease (COVID-19). Retrieved from http://kemdikbud.go.id/main/files/download/c5d9f0ec9ff40c6 (2020b)

[14] Mohammadi, N., Ghorbani, V., \&Hamidi, F: Effects of e-learning on language learning. Vol. 3, pp 464-468. Procedia Computer Science (2011)

[15] Nugroho, Arif: EFL Classes Must Go Online! Teaching Activities and Challenges during COVID19 Pandemic in Indonesia. Vol. 13, pp. 49-76. Register Journal (2020)

[16] Okmawati, Mike: The Use of Google Classroom During Pandemic. Vol. 9, pp. 438-443. Journal of English Language Teaching (2020)

[17] Oxford, R.L, and J Shearin: Language Learning Motivation: Expanding the Theoretical Framework. Vol. 78, pp. 12-28. The Modern language Journal (1994)

[18] Raheem, BareqRaad., \&M.Amirullah Khan: The Role Of E-Learning In Covid-19 Crisis. Vol. 8, pp. 3135-3138. International Journal of Creative Research Thought (2020)

[19] [19] Sadeghi, Manijeh: A shift from Classroom to a Distance Learning: Advatages and Limitation. Vol.4, pp. 80-88. International Journal of Reasearch in English Education (2019)

[20] Sukmawati\&Nensia: The Role of Google Classroom in ELT. Vol.1, pp. 142-145. International Journal for Educational and Vocational Studies (2019)

[21] Velavan, T. P., \& Meyer, C. G. The COVID-19 Epidemic. TropicalMedicine and International Health, 25(3), 278-280. https://doi.org/10.1111/tmi.13383 (2020)

[22] WHO? Coronavirus Disease 2019 (COVID-19) Situation Report - 72. Retrieved from https://www.who.int/docs/defaultsource/coronaviruse/situation-reports/2020401-sitrep-72covid19.pdf?sfvrsn=3dd8971b_2 (2020) 